\title{
Economic analysis of application of phosphorus, single and dual inoculation of Rhizobium and plant growth promoting rhizobacteria in lentil (Lens culinaris Medikus)
}

\author{
Narinder Singh $^{1 *}$, Guriqbal Singh ${ }^{2}$ and Navneet Aggarwal ${ }^{2}$ \\ ${ }^{1}$ Department of Agronomy, Punjab Agricultural University, Ludhiana-141004 (Punjab), INDIA \\ ${ }^{2}$ Department of Plant Breeding and Genetics, Punjab Agricultural University, Ludhiana-141004 (Punjab), INDIA \\ *Corresponding author. E-mail: nsbamra90.pau@gmail.com
}

Received: October 24, 2016; Revised received: February 7, 2017; Accepted: May 6, 2017

\begin{abstract}
This study investigates the economic returns of lentil (Lens culinaris Medikus) by the use of phosphorus and biofertilizers [Rhizobium and plant growth promoting rhizobacteria (PGPR)] in Indian Punjab. The field experiments were conducted during Rabi 2013-14 and 2014-15 with combinations of four levels of phosphorus $(0,20,30$ and $40 \mathrm{~kg} \mathrm{P}_{2} \mathrm{O}_{5}$ ha $^{-1}$ ) and two/four biofertilizer treatments [uninoculated control and Rhizobium (LLR 12) + PGPR (RB 2)] in 2013-14, and uninoculated control, Rhizobium, PGPR and Rhizobium + PGPR in 2014-15) by replicating thrice. The use of $40 \mathrm{~kg} \mathrm{P}_{2} \mathrm{O}_{5} \mathrm{ha}^{-1}$ provided the highest gross returns whereas net returns and $\mathrm{B}: \mathrm{C}$ were highest at $30 \mathrm{~kg} \mathrm{P}_{2} \mathrm{O}_{5} \mathrm{ha}^{-1}$. The combination of Rhizobium $+\mathrm{PGPR}+40 \mathrm{~kg} \mathrm{P}_{2} \mathrm{O}_{5}$ ha $^{-1}$ provided the highest gross returns (Rs. 45902) whereas Rhizobium + PGPR+ $20 \mathrm{~kg} \mathrm{P}_{2} \mathrm{O}_{5} \mathrm{ha}^{-1}$ provided the highest net returns (Rs 20620). Furthermore, the integrated use of Rhizobium + PGPR $+20 \mathrm{~kg} \mathrm{P}_{2} \mathrm{O}_{5}$ ha $^{-1}$ provided higher net returns (Rs 20620) and $\mathrm{B}: \mathrm{C}(1.88)$ as compared to sole application of $40 \mathrm{~kg} \mathrm{P}_{2} \mathrm{O}_{5} \mathrm{ha}^{-1}$ (Rs 18792 and 1.72). Thus, there was a net saving of $20 \mathrm{~kg} \mathrm{P}_{2} \mathrm{O}_{5} \mathrm{ha}^{-1}$ with the use of Rhizobium + PGPR inoculation without sacrificing the economics returns.
\end{abstract}

Keywords: B:C, Biofertilizers, Gross returns, Lentil, Net returns, Phosphorus

\section{INTRODUCTION}

Lentil (Lens culinaris Medikus) is recognised as an important grain legume crop in the world. In India, during the year 2014, lentil was grown on an area of 1.80 million hectares and total production was 1.10 million tonnes, with productivity of $611 \mathrm{~kg} \mathrm{ha}^{-1}$ (FAOSTAT 2017). Pulses are the wonder crops as these are a rich source of protein for vegetarian inhabitants and also have an ability to reduce the pressure of external inorganic $\mathrm{N}$ inputs because of biological nitrogen fixation process. In lentil, estimated nitrogen obtained from $\mathrm{N}_{2}$ fixation is $51 \mathrm{~kg} \mathrm{~N} \mathrm{ha}^{-1}$ year $^{-1}$ (Smil 1999). These crops are used for crop diversification in different cropping systems.

Continuous hike in the prices of non-renewable resources and inorganic fertilizers forced to increase the agriculture production by adopting new strategies including the use of biofertilizers (e.g. Rhizobium) and integrated use of organic and chemical fertilizers. Phosphorus fertilizer is considered as the limiting factor in pulse production technology. No doubt the use of some chemical fertilizers (such as phosphorus and potash supplying fertilizers) supply nutrients to the crop plants, however, their overexploitation adversely affects the Indian economy by disturbing foreign exchange via increasing import of fertilizers and, there- fore, forces to pay attention to find out the economic doses of fertilizers. For increasing their profits, farmers try to make best investments through farming practices, however, there is a great need to make them aware about the use of microbial inoculations along with fertilizer application (Uddin et al. 2014).

Beneficial effects of Rhizobium are already known (Singh et al. 2006), however, recent research has shown beneficial effects of plant growth promoting rhizobacteria (PGPR) also (Kaur et al. 2015). Biofertilizers such as Rhizobium and PGPR are eco-friendly, low in cost and also they have an ability to recycle the indigenous or immobile nutrients in sustainable agriculture. Rhizobium fixes atmospheric nitrogen and converts it in plant usable form while PGPR augment the plant growth by different ways. Direct promotion of plant productivity by use of PGPR occurs, when rhizobacteria improve the supply of nutrients i.e. nitrogen, production of metabolites such as auxins, cytokinins and gibberellins as well as through the solubilization of phosphate and other minerals. Under indirect plant growth promotion, PGPR eliminate the pathogens by the production of cyanide, siderophores, chitinase etc. Application of nutrients at proper dose helps to achieve profitable and also economically and environmentally best while higher dose not only increases the cost of production but also results in environmental 
pollution. When maximum returns per unit of fertilizer are recorded then fertilizers are considered as the efficiently used (Mortvedt et al. 2001). Along with enhancing grain yield and making available soil fixed $\mathrm{P}$, microbial inoculations may also help in lowering the cost of crop production through less input of chemical fertilizers. Therefore, agronomic experiments were conducted to find out the best combinations of inorganic fertilizers and biofertilizers for lentil crop from economics point of view.

\section{MATERIALS AND METHODS}

The present field research was carried out at Punjab Agricultural University, Ludhiana $\left(30^{\circ} 54^{\prime} \mathrm{N}\right.$ latitude and $75^{\circ} 56^{\prime}$ E longitude), Punjab during Rabi season of 2013-14 and 2014-15. The location of the experimental farm is located in Trans-Gangetic agro-climatic zone of India, under the central plain region of Punjab. The soil of experimental farm was loamy sand in textural class with low organic carbon $(0.32 \%) \&$ available $\mathrm{N}$ $\left(119.8 \mathrm{~kg} \mathrm{ha}^{-1}\right)$ and medium in available $\mathrm{P}(13.6 \mathrm{~kg}$ ha $\left.{ }^{1}\right)$ \& available $\mathrm{K}\left(161 \mathrm{~kg} \mathrm{ha}^{-1}\right)$. The experiment comprised combinations of four levels of phosphorus $(0$, 20, 30 and $40 \mathrm{~kg} \mathrm{P}_{2} \mathrm{O}_{5} \mathrm{ha}^{-1}$ ) and two/four biofertilizer treatments [uninoculated control and Rhizobium + plant growth promoting rhizobacteria (PGPR) in 201314] and (uninoculated control, Rhizobium, PGPR and Rhizobium + PGPR in 2014-15) replicated three times in Randomized Complete Block Design (RCBD).

Sowing of lentil cultivar 'LL 699' was done on 11November 2013 and 6 November 2014. As per the treatments, phosphorus was applied through single superphosphate $\left(16 \% \mathrm{P}_{2} \mathrm{O}_{5}\right)$ at sowing. Seeds were inoculated with Rhizobium (LLR 12) and PGPR (RB 2) prior to sowing as per treatments. Rhizobium and PGPR were used as single inoculations or as dual inoculation (Rhizobium + PGPR) as per the treatments. Inoculated seeds were dried in shade before sowing. A uniform basal dose of $\mathrm{N}$ fertilizer at $12.5 \mathrm{~kg} \mathrm{ha}^{-1}$ through urea $(46 \% \mathrm{~N})$ was broadcasted at the time of sowing. The crop was harvested on 8 April and 14 Aprilin 2014 and
2015, respectively. The crop was raised as per the recommendations (PAU, 2013).

For calculating gross returns, the grain yield was multiplied by minimum support price (MSP) i.e. Rs. 2950 quintal $^{-1}$. The cost of cultivation (i.e. total variable costs) includes different variable costs like human labour, machinery energy, seed, fertilizer, biofertilizers, insecticide, irrigation, etc. The details of the costs involved in different inputs are presented in Table 1.Net returns were calculated by subtracting total variable costs from the gross returns. The benefit cost ratio (B:C) was calculated by dividing the gross returns with total cost of cultivation. The gross returns and net returns were expressed in Rs. ha ${ }^{-1}$.

\section{RESULTS AND DISCUSSION}

Gross returns: Gross returns increased with the successive increase in phosphorus dose from 0 to $40 \mathrm{~kg}$ $\mathrm{P}_{2} \mathrm{O}_{5}$ ha $^{-1}$ (Tables 2 and 3). The lowest gross returns were obtained in the control treatment i.e. where no phosphorus and biofertilizers were applied. Among biofertilizer treatments, higher gross returns were obtained from coinoculated treatment (Rhizobium + PGPR) than uninoculated control or sole inoculations of Rhizobium and PGPR. Earlier, Jain et al. (2006) also reported that the highest net returns from coinoculation might be due to maximum grain and straw yield.

The highest gross returns were fetched by combined application of Rhizobium + PGPR $+40 \mathrm{~kg} \mathrm{P}_{2} \mathrm{O}_{5} \mathrm{ha}^{-1}$ (Rs 45902) (Table 2), which might be due to higher grain yields. As compared to the sole application of 20, 30 and $40 \mathrm{~kg} \mathrm{P}_{2} \mathrm{O}_{5} \mathrm{ha}^{-1}$, the integrated use of phosphorus and biofertilizers (Rhizobium, PGPR and Rhizobi$u m+$ PGPR) improved gross returns. Application of a unit fertilizer is economical, if the value of the increase in the crop yield due to the quantity of fertilizer added is greater than the cost of fertilizer used. If a unit of fertilizer does not increase the yield enough to pay for its cost, its application will not be economical and will not return profit even after a constant increase in the yield (Singh 2004). The application of essential plant

Table 1. Level of input of biofertilizers and phosphorus use for different treatments for lentil cultivation.

\begin{tabular}{lc}
\hline Type of input & Cost (Rs ha $\left.\mathbf{~}^{-\mathbf{1}}\right)$ \\
\hline Rhizobium & 50 \\
PGPR & 50 \\
Rhizobium + PGPR & 100 \\
$20 \mathrm{~kg} \mathrm{P}_{2} \mathrm{O}_{5} \mathrm{ha}^{-1}$ & 2862 \\
$30 \mathrm{~kg} \mathrm{P}_{2} \mathrm{O}_{5} \mathrm{ha}^{-1}$ & 4292 \\
$40 \mathrm{~kg} \mathrm{P}_{2} \mathrm{O}_{5} \mathrm{ha}^{-1}$ & 5725 \\
Labour charges for Rhizobium inoculation & 50 \\
Labour charges for PGPR inoculation & 50 \\
Labour charges for Rhizobium + PGPR inoculation & 50 \\
General cost of cultivation (except the treatment costs) & 20500 (in 2013-14) \\
& 22500 (in 2014-15) \\
\hline
\end{tabular}


Table 2. Effect of phosphorus and biofertilizers on economic returns of lentil in 2013-14.

\begin{tabular}{|c|c|c|c|c|}
\hline \multirow[t]{2}{*}{ Treatment } & \multirow{2}{*}{$\begin{array}{c}\text { Cost of cultivation } \\
\left(\mathrm{Rs} \mathrm{ha}^{-1}\right)\end{array}$} & \multicolumn{2}{|c|}{ Returns (Rs ha $\left.{ }^{-1}\right)$} & \multirow[t]{2}{*}{$\mathrm{B}: \mathrm{C}^{*}$} \\
\hline & & Gross & Net & \\
\hline $0 \mathrm{~kg} \mathrm{P}_{2} \mathrm{O}_{5} \mathrm{ha}^{-1}$ (unfertilized control) & 20500 & 35400 & 14900 & 1.73 \\
\hline $20 \mathrm{~kg} \mathrm{P}_{2} \mathrm{O}_{5} \mathrm{ha}^{-1}$ & 23362 & 40644 & 17282 & 1.74 \\
\hline $30 \mathrm{~kg} \mathrm{P}_{2} \mathrm{O}_{5} \mathrm{ha}^{-1}$ & 24792 & 43704 & 18912 & 1.76 \\
\hline $40 \mathrm{~kg} \mathrm{P}_{2} \mathrm{O}_{5} \mathrm{ha}^{-1}$ & 26225 & 45015 & 18790 & 1.72 \\
\hline Rhizobium + PGPR & 20650 & 41081 & 20431 & 1.99 \\
\hline Rhizobium $+\mathrm{PGPR}+20 \mathrm{~kg} \mathrm{P}_{2} \mathrm{O}_{5} \mathrm{ha}^{-1}$ & 23512 & 44141 & 20629 & 1.88 \\
\hline Rhizobium $+\mathrm{PGPR}+30 \mathrm{~kg} \mathrm{P}_{2} \mathrm{O}_{5} \mathrm{ha}^{-1}$ & 24942 & 44578 & 19636 & 1.79 \\
\hline Rhizobium $+\mathrm{PGPR}+40 \mathrm{~kg} \mathrm{P}_{2} \mathrm{O}_{5} \mathrm{ha}^{-1}$ & 26375 & 45889 & 19514 & 1.74 \\
\hline$C D(p=0.05)$ & & 5281 & NS & NS \\
\hline
\end{tabular}

* B:C $=$ Benefit Cost Ratio

Table 3. Effect of phosphorus and biofertilizers on economic returns of lentil in 2014-15.

\begin{tabular}{|c|c|c|c|c|}
\hline \multirow[t]{2}{*}{ Treatment } & \multirow[t]{2}{*}{ Cost of cultivation ( $\left.\mathrm{Rs} \mathrm{ha}^{-1}\right)$} & \multicolumn{2}{|c|}{ Returns (Rs. ha ${ }^{-1}$ ) } & \multirow[t]{2}{*}{$\mathrm{B}: \mathrm{C}^{*}$} \\
\hline & & Gross & Net & \\
\hline \multicolumn{5}{|l|}{$\mathrm{P}_{2} \mathrm{O}_{5}\left(\mathrm{~kg} \mathrm{ha}^{-1}\right)$} \\
\hline 0 & 22587 & 47140 & 24553 & 2.08 \\
\hline 20 & 25449 & 53534 & 28085 & 2.10 \\
\hline 30 & 26879 & 56402 & 29523 & 2.09 \\
\hline 40 & 28312 & 57377 & 29065 & 2.02 \\
\hline$C D(p=0.05)$ & & 1607 & 1607 & NS \\
\hline \multicolumn{5}{|l|}{ Biofertilizers } \\
\hline Uninoculated & 25719 & 50454 & 24735 & 1.96 \\
\hline Rhizobium & 25819 & 53845 & 28026 & 2.08 \\
\hline PGPR & 25820 & 52838 & 27018 & 2.04 \\
\hline Rhizobium + PGPR & 25869 & 57316 & 31447 & 2.21 \\
\hline$C D(p=0.05)$ & & 1607 & 1607 & 0.06 \\
\hline
\end{tabular}

* $\mathrm{B}: \mathrm{C}=$ Benefit Cost Ratio

nutrients in optimum quantity and right proportion is the key to increase the profit.

Net returns: Among different phosphorus levels, 30 $\mathrm{kg} \mathrm{P}_{2} \mathrm{O}_{5} \mathrm{ha}^{-1}$ provided the highest net returns (Tables 2 and 3). Among biofertilizer treatments, the coinoculated treatment gave higher net returns than uninoculated control (Table 2) and uninoculated control as well as single inoculations of Rhizobium and PGPR (Table 3). Similarly in chickpea, higher net returns (Rs 11312ha $\left.{ }^{1}\right)$ with the application of Rhizobium + phosphorus solubilising bacteria over the uninoculated control (Rs $8282 \mathrm{ha}^{-1}$ ) and single inoculations of Rhizobium (Rs $9883 \mathrm{ha}^{-1}$ ) and PGPR (Rs $9697 \mathrm{ha}^{-1}$ ) were reported by Jain et al. (2006).

The highest net returns were fetched by integrated use of Rhizobium + PGPR + $20 \mathrm{~kg} \mathrm{P}_{2} \mathrm{O}_{5} \mathrm{ha}^{-1}$ (Rs 20620) (Table 2), which might be due to high grain yield and less cost of cultivation. Earlier, Jain et al. (2006) reported that improvement in net returns (Rs $22067 \mathrm{ha}^{-1}$ ) was due to higher gross returns (Rs $30538 \mathrm{ha}^{-1}$ ) in chickpea. Application of $20 \mathrm{~kg} \mathrm{P}_{2} \mathrm{O}_{5} \mathrm{ha}^{-1}$ with consortium (Rhizobium + PGPR) was more profitable over 40 $\mathrm{kg} \mathrm{P}_{2} \mathrm{O}_{5} \mathrm{ha}^{-1}+$ Rhizobium + PGPR, that might be due to low cost of single superphosphate and biofertilizers in comparison to the additional grain yield obtained (Kanwar et al. 2013). Thus, there was a net saving of $20 \mathrm{~kg} \mathrm{P}_{2} \mathrm{O}_{5}$ ha $^{-1}$ with the useof Rhizobium $+\mathrm{PGPR}+20$ $\mathrm{kg} \mathrm{P}_{2} \mathrm{O}_{5}$ ha $^{-1}$ over Rhizobium $+\mathrm{PGPR}+40 \mathrm{~kg} \mathrm{P}_{2} \mathrm{O}_{5}$ ha ${ }^{1}$ or $40 \mathrm{~kg} \mathrm{P}_{2} \mathrm{O}_{5} \mathrm{ha}^{-1}$ alone without sacrificing the economic returns.

Benefit cost ratio: Among different phosphorus levels, 20 and $30 \mathrm{~kg} \mathrm{P}_{2} \mathrm{O}_{5}$ ha $^{-1}$ provided higher $\mathrm{B}: \mathrm{C}$ than 0 and $40 \mathrm{~kg} \mathrm{P}_{2} \mathrm{O}_{5}$ ha $^{-1}$ (Tables 2 and 3), though the results differed non significantly in 2014-15. Among bioferti- 
lizer treatments, coinoculation treatment resulted in significantly higher $\mathrm{B}: \mathrm{C}$ than uninoculated control (Table 2) and uninoculated control as well as single inoculation of Rhizobium or PGPR (Table 3).

Higher B:C was obtained in combined use of Rhizobi$u m+$ PGPR $+20 \mathrm{~kg} \mathrm{P}_{2} \mathrm{O}_{5} \mathrm{ha}^{-1}$ (1.88) than all other treatments except Rhizobium + PGPR (Table 2). These results are similar with the findings of Jain et al. (2006) who reported that this was due to more uptake of nutrients ( $\mathrm{N}$ and $\mathrm{P}$ ) that increased the grain yield. Minimization in dose of phosphorus and subsequently reduction of cost per unit production through higher yield helps to get maximum benefits. Application of either phosphorus or biofertilizers was unable to give better B:Cthan that given by combined application of both. It shows the importance of both biofertilizers and fertilizers. In chickpea, compared to phosphorus fertilizers, the low cost of biofertilizers is responsible to improve the $\mathrm{B}: \mathrm{C}$ ratio in PGPR (4.33) over the uninoculated control (3.54) (Tanwar et al. 2010).

\section{Conclusion}

It may be concluded that to obtain the higher profit it is necessary to use the fertilizers as efficiently as possible without any wastage or losses. The use of $40 \mathrm{~kg} \mathrm{P}_{2} \mathrm{O}_{5}$ $\mathrm{ha}^{-1}$ provided the highest gross returns (Rs. $45015 \mathrm{ha}^{-1}$ for 2013-14 and Rs. $57377 \mathrm{ha}^{-1}$ for 2014-15) where as net returns (Rs. $18912 \mathrm{ha}^{-1}$ for 2013-14 and Rs. 29523 $\mathrm{ha}^{-1}$ for 2014-15) and B:C (1.76 for 2013-14 and 2.09 for 2014-15) were highest at $30 \mathrm{~kg} \mathrm{P}_{2} \mathrm{O}_{5} \mathrm{ha}^{-1}$. Dual inoculation with Rhizobium and PGPR was better over uninoculated control or single inculcations. As compared to sole application of chemical fertilizer or inoculation, the integrated use of $20 \mathrm{~kg} \mathrm{P}_{2} \mathrm{O}_{5}$ ha $^{-1}+$ Rhizobi$u m+$ PGPR was found to be the most promising treatment. The saving in $20 \mathrm{~kg} \mathrm{P}_{2} \mathrm{O}_{5} \mathrm{ha}^{-1}$ was possible because of the use of biofertilizers which increased the efficiency of applied phosphorus.

\section{ACKNOWLEDGEMENTS}

The authors are thankful to the Punjab Agricultural University, Ludhiana, India for providing facilities for conducting these trials. Thanks are also due to $\mathrm{Dr}$ (Mrs) Veena Khanna, Senior Microbiologist, for providing the cultures of biofertilizers.

\section{REFERENCES}

FAOSTAT (2017). Area and production of lentil in India from http://www.fao.org/faostat/en/\#data/QC. (Verified on $7 / 2 / 2017$ ).

Jain, L. K., Singh, P. and Balyan, J. K. (2006).Productivity and profitability of chickpea (Cicer arietinum L.) cultivation as influenced by biofertilizers and phosphorus fertilization. Indian Journal of Dryland Agricultural Research and Development,21: 201-203

Kanwar, P., Singh, P., Singh, P. and Singh, P. (2013). Effect of Rhizobium, PSB and phosphorus on yield and economics of mungbean. Annals of Plant and Soil Research, 15: 164-166

Kaur, J., Khanna, V., Kumari, P. and Sharma, R. (2015). Influence of psychrotolerant plant growth promoting rhizobacteria (PGPR) as coinoculants with Rhizobium on growth parameters and yield of lentil (Lens culinaris Medikus). African Journal of Microbiology Research, 9: 258-264

Mortvedt, J. J., Murphy, L. S. and Follett, R. H. (2001). Fertilizer Technology and Application. Meister Publishing Co, Willoughby, OH, USA.

PAU (2013). Packages of Practices for Rabi Crops of Punjab. Punjab Agricultural University, Ludhiana, India.

Singh, S. S. (2004). Soil Fertility and Nutrient Management, 2nd Edition. Kalyani Publishers, New Delhi, India.

Singh, G., Sekhon, H. S. and Sharma, P. (2006). Effect of Rhizobium, phosphorus and potash on nodulation and productivity of lentil (Lens culinaris Medik.). TheJournalof Plant Science Research, 22:239-241

Smil, V. (1999). Nitrogen in crop production: An account of global flows. Global Biogeochemical Cycles, 13: 647662

Tanwar, S. P. S., Rokadia, P. and Singh, A. K. (2010). Productivity, nutrient balance and economics of kabuli chickpea (Cicer kabulium) as influenced by integrated nutrient management. Indian Journal of Agronomy, 55: 33-37

Uddin, M., Hussain, S., Khan, M. M. A., Hashmi, N., Idrees, M., Naeem, M. and Dar, T. A. (2014). Use of N and P biofertilizers reduces inorganic phosphorus application and increases nutrient uptake, yield and seed quality of chickpea. Turkish Journal of Agriculture and Forestry, 38: 47-54 